\title{
What are the methodological designs of nihr funded clinical trials? Going beyond routine data collection
}

\author{
Amanda Young ${ }^{*}$, Helen Buxton, Liz Tremain, Tom Kenny \\ From 3rd International Clinical Trials Methodology Conference \\ Glasgow, UK. 16-17 November 2015
}

\section{Background}

In 2015, a report was published in the Health Technology Assessment which piloted the use of extracting metadata on the design, conduct, results and costs of clinical trials funded by the Health Technology Assessment programme. A recommendation was to explore the feasibility of extracting data on the active NIHR portfolio of clinical trials.

\section{Aims and objectives}

To develop and pilot a method to capture data on the design and methodology of all active NIHR funded clinical trials.

\section{Method}

We will review the NIHR portfolio of clinical trials that have an active status (from pre-contracting status to submission of final report) from data extracted in November 2014. The first part of the pilot will extract data on the design and methodological features of a clinical trial, using the existing data fields from the metadata database published in the 2015 HTA report.

\section{Results}

The key findings will include an overview of the type of clinical trials funded by NIHR and whether there are differences between the NIHR Programmes. Particular attention will be paid to key methodological elements such as the design framework, number of arms and primary outcomes and the type of interventions.

\section{Conclusions}

Examining the methodological design of NIHR clinical trials is important to maximise the added value of metadata

$$
\text { National Institute for Health Research, Evaluation, Trials and Studies }
$$$$
\text { Coordinating Centre, Southampton, UK }
$$

(c) 2015 Young et al. This is an Open Access article distributed under the terms of the Creative Commons Attribution License (http:// creativecommons.org/licenses/by/4.0), which permits unrestricted use, distribution, and reproduction in any medium, provided the original work is properly cited. The Creative Commons Public Domain Dedication waiver (http://creativecommons.org/publicdomain/ zero/1.0/) applies to the data made available in this article, unless otherwise stated. approaches beyond routine data collection and for increasing awareness of the type of trials funded by NIHR.

Published: 16 November 2015

doi:10.1186/1745-6215-16-S2-P43

Cite this article as: Young et al:: What are the methodological designs of nihr funded clinical trials? Going beyond routine data collection. Trials 2015 16(Suppl 2):P43.
Submit your next manuscript to BioMed Central and take full advantage of:

- Convenient online submission

- Thorough peer review

- No space constraints or color figure charges

- Immediate publication on acceptance

- Inclusion in PubMed, CAS, Scopus and Google Scholar

- Research which is freely available for redistribution
C Biomed Central 